
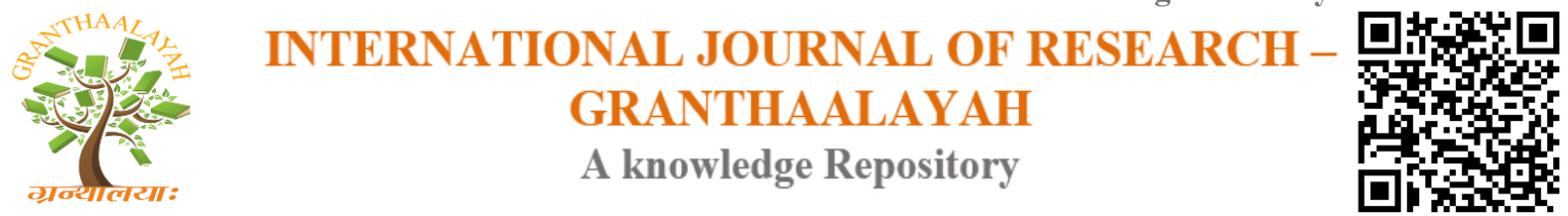

Management

\title{
GOLD AND OIL PRICES VERSUS STOCK EXCHANGE: A CASE STUDY OF PAKISTAN
}

\author{
Rabia Najaf ${ }^{1}$, Khakan Najaf $^{2}$, Salman Yousaf ${ }^{3}$ \\ ${ }^{1}$ University of Lahore, Lahore, PAKISTAN \\ ${ }^{2,3}$ Punjab group of college, PAKISTAN
}

\begin{abstract}
Due to global financial crisis, around the all over the world all developing and under developing countries are facing the low trading profit. In most of the developing country like Pakistan, there is low investment level due to political instability. Due to this condition Karachi stock exchange has the worst sell .Karachi stock exchange is known as the oldest and more profitable stock exchange of Pakistan oil and gold prices are attracting investors towards there not in the stock exchange. This thing is the barrier for the progress of the development of the country. This paper is trying to expose that stock market is going to down due to these variables. For checking the impact of oil and gold prices on the Karachi stock exchange. We have used that secondary data for this study. For this purpose we have taken data from Karachi stock exchanges from the period of 1996 to 2013. We have applies correlation matrix for this purpose. the result has shown that KSE 100 has return is 0.014503 and GDP 0.058793 ,gold 0.012026 and oil 0.00919.karachi stock exchange return has standard value is 0.089982 , while gold standard deviation 0.038716 and oil standard deviation value is 0.103375 . The correlations have shown that in these markets there is not positive relationship.karachi stock exchange and GDP have inverse relationship with gold market. These results have also shown that oil growth has a significant relationship with KSE100 and GDP.For the predication correlation is not considering an authentic measure.
\end{abstract}

Keywords:

Oil prices, gold prices, GDP.karachi stock exchanges.

Cite This Article: Rabia Najaf, Khakan Najaf, and Salman Yousaf, "GOLD AND OIL PRICES VERSUS STOCK EXCHANGE: A CASE STUDY OF PAKISTAN" International Journal of Research - Granthaalayah, Vol. 4, No. 2 (2016): 129-138.

\section{INTRODUCTION}

Investment is such money which is put away for the purpose of future use. There is a lot of way through which investors can invest their money for example in the shape of gold, foreign currency etc .In the shape of investment of gold investors have found significant benefits. The investment in gold is known as tangible assets investments .According to different investors the 
gold is known as much trusted investments.Gold is also known as quite safe investment from the financial crisis .It has been seen that gold is less risky investment then others assets. Past studies have proved that there is significant relationship between gold prices and stock market. It could be consider the gold as a safe heaven investment.

The purpose of this study is to show the relationship between stock market and oil and gold prices. Oil prices have a crucial role for the determinations of prices of industries. Oil prices have direct and indirect effect on the economy of any develop and underdeveloped country. Earning of the entire companies decline due to increases the prices of the oil. Hassan and Nasir (2008) have shown that there is strong relationship between stock prices and stock market investment.Similarly, oil prices is the attractive way to support the investment of the stock market. Gold price presenting the relationship between interest rate and inflation rate. According to Irshad, (2013) there is imperfections in the stock market of Pakistan. Oil prices have impact on the things prices.

Researchers always take oil as debatable variable for analyzing the economy of the country.Inceaser in the oil prices depends upon the overall GDP.In Pakistan; there are some issues about the availability of oil.

\begin{tabular}{|l|l|l|l|l|}
\hline Years & \multicolumn{1}{l|}{$\begin{array}{l}\text { World } \\
\text { Crude Oil }\end{array}$} & \multicolumn{1}{l|}{$\begin{array}{l}\text { Pakistan Oil } \\
\text { Prices }\end{array}$} & $\begin{array}{l}\text { U.S.A } \\
\text { Prices }\end{array}$ \\
\hline \$/barrel & \multicolumn{4}{|c|}{ Obarrel } \\
\hline 1990 & 23.84 & 22.18 & \multicolumn{1}{|l|}{$\mathbf{\text { /barrel }}$} \\
\hline 1991 & 18.445 & 19.189 & 18.52 \\
\hline 1992 & 19.6 & 18.25 & 17.38 \\
\hline 1993 & 17.145 & 15.66 & 15.4 \\
\hline 1994 & 15.89 & 15.398 & 14.28 \\
\hline 1995 & 17.02 & 16.76 & 11.92 \\
\hline 1996 & 18.57 & 19.45 & 19.42 \\
\hline 1997 & 19.32 & 18.72 & 17.93 \\
\hline 1998 & 13.278 & 12.16 & 11.48 \\
\hline 1999 & 18.04 & 17.39 & 16.4 \\
\hline 2000 & 28.76 & 26.84 & 27.46 \\
\hline 2001 & 25.04 & 23.12 & 22.84 \\
\hline 2002 & 52.4 & 24.35 & 23.33 \\
\hline 2003 & 28.69 & 27.68 & 28.47 \\
\hline 2004 & 37.723 & 34.57 & 37.72 \\
\hline 2005 & 54.36 & 50.27 & 51.27 \\
\hline 2006 & 65.83 & 62.18 & 61.18 \\
\hline 2007 & 72.32 & 68.74 & 65.74 \\
\hline 2008 & 101.39 & 94.78 & 95.78 \\
\hline
\end{tabular}

\section{OVERVIEW OF KARACHI STOCK MARKET}

Currently, in Pakistan there is three stock exchange 1) karachi2) lahore3) Islamabad stock exchnage.karachi stock exchange is known as oldest stock exchange of Pakistan and it has a number of listed companies. In Pakistan there have been taken different steps for foreign investments. However, political stability has seen a main determinates for disturbing the stock exchange of Pakistan. In Asia the return of Karachi stock exchange is higher than other stock exchange. Form the last few decades the performance of Karachi stock exchange was 
remarable.In Karachi stock exchange the no of listed companies are 652. After the 1947, Karachi stock exchange was established in Karachi .It is a hub of trading activities in Pakistan. In 1950, it was registered after its establishment; there were just five listed companies. In 1950, Karachi stock exchange was first time computerized .Due to latest work of Karachi stock exchange the demand of trading is increasing rapidly. Hence, these trading activities are readily increasing day by day. In the last decade of the $20^{\text {th }}$ century Karachi stock exchange was famous with the name of the KSE 50 index. In 1995 it is known as the KSE all share and in 2006 it is known as the KSE 30 index. Currently, it is known as the oldest stock exchange of Pakistan. After the 2010, the volume and capitalization of Karachi stock exchange are 13 US dollar and 32.5 US dollar.

\section{GOLD AND OIL PRICES IN PAKISTAN}

In Pakistan from last few decades the Gold prices was very high .It has reached till 55 thousands in these years the international gold market were also affected. Increase in the prices of gold have badly affected on the economy. Gold prices are known as the best indicator for the economy of healthy economy. The decrease in the gold prices means economy is going downward direction.

Oil cost is known as the basic aspect for determining the industrial production. Gold cost has effected on the worldwide development of economy. In 2005, the international economy was in the position of downturn because cost of gold was near about US \$416 per ounces. According to different researchers gold is known as the store of the value. In nov 2010 the gold cost was at the peak it was US\$ 1421 per ounces. the association between gold rate and interest rate is negative.

Marx s concept of cash was very crucial aspect for describing about adoption of cash. Prices of gold can be predicated on the basic on the predication. Researchers have proved that there is no connection between oil costs and gold costs. Pakistan has financial development is $7 \%$ while it is seen that after its freedom its financial development is not more than 5\%.pakistan financial development has been dropped at 2.7\%.low financial development is the first barrier for the development of country. Due to these financial crisis the Pakistan s hardship was affected Badly.governemnt of Pakistan have taken 715 billion for the improvement of poverty of Pakistan. Pakistan has financial development is $7 \%$ while it is seen that after its freedom its financial development is not more than 5\%.pakistan financial development has been dropped at 2.7\%.low financial development is the first barrier for the development of country. Due to these financial crisis the Pakistan s hardship was affected Badly.governemnt of Pakistan have taken 715 billion for the improvement of poverty of Pakistan. In the modern era the oil crisis is the blood for every economics. It is true that oil prices have helped out the maintain the level of oil prices. We are trying to find out the impact of oil prices on stock market. We also try to explore that investors would like to invest in stock market or gold prices. There is reserved work related to impact of oil crisis on the stock exchange. There are three main researchers related prediction of economy growth. According to Swarovski (1999) have proved that oil prices have on the economic growth of India. There are three main researchers related to explore the impact of oil prices on the stock exchange.

According to Kabul [5] oil prices increases and decrease have impact on the growth of any economy. Oil prices are the resource of economic growth instability. 


\section{LITERATURE REVIEW}

Blose and Shieh [5] in their article they are trying to explore that Gold is the portfolio diversifier and stock market is the macroeconomic risk. For this purpose they used probity economic model and take the data from 1998 to 2012.They are concluded that gold investment is much beneficial rather than stock investment.

Büyüksalvarc [10] the prime aim of this study is to show the impact of oil and gold on the stock market of Pakistan. For this purpose he has taken a monthly data from January 2001 to December 2011.For checking that data is stationary or not they have used the ADF test and proved that data is not stationary. His results of correlation have shown that there is not significant relationship between the variables. He has also used the variance decomposition for the checking the variance between the variables.

Capiand and Wood [5] in their paper they have investigated that relationship between gold prices and US dollar.For this purpose they used the monthly data from Jan 2000 to Dec 2011 and used the GARCH model. Their results have shown that there is positive relationship between gold prices and US dollar.

Dickey and W.A [9] they are tried to explore that investors do not react rational in the case of changing the prices of goods and services. For this purpose they used the Johnson approach and have taken the data from year 2003 to 2013 and showed that result that there is no long run relationship between oil prices and stock market.

Husing and $\mathrm{Yu}$ [7] in this study they have studied that the impact of monetary policy on the oil prices of pakaistan. For this purpose they have taken monthly data and used the bivariate model for this purpose. They concluded that there is negative relationship between monetary policy and oil prices of Pakistan.

Ahmet [7] in this paper he has applied simultaneous equation model. This paper is trying to show that if the oil prices increase then real GDP would decrease till $0.45 \%$. This paper is also trying to show that stock prices have negative impact on the real deprecation.

Basher and Sadorsky [6] in this paper they are trying to find out the oil and gold prices impact on the KSE 100 index. In this paper they have taken KSE100 index as a dependent variable and oil and gold prices as dependent variable. They used regression model for this purpose and proved that there is no obvious relationship between them.

Claire, Ginette, Rajneesh and Ahmet [2009] in this paper they are trying to expose that impact of macroeconomic variables on the Korea stock exchange and for this purpose they have used the cointrgartion and causality test. Their results have shown that there is short run relationship between them.

Hamed Sadri and Ehsan TayebiSani [12] in this paper they have examined the dynamic relationship between oil prices and Karachi stock exchange for this purpose they have used the VECM model and showed the results that there is unidirectional relationship between them. 
Hamed Sadri and Ehsan TayebiSani [12] in this paper they have applied the GARCH model and taken the data from 1998 to 2008.regrading to their results that short run relationship between oil and gold prices and stock exchange.

Basher and Sadorsky, [6] in this paper they have analyzed the impact of two variables on stock exchange of india,for this purpose they have used the data from 1998 to 2008. They have applied the GARCH model and take the resulted that there is short run relationship between them.

Subarna,Samanta and Ali [11] the impact of oil prices on the stock market of India. For this purpose they have used the secondary data from the year 1991 to 2012. They have used then Johenden cointegartion test. They have found the result that there is long run relationship between them.

Mahmood Yahyazadehfar and Ahmad Babaie [12] The main object of this study is to investigate the impact of gold and oil prices on the stock market of the Iran for this purpose they have used VAR model they have concluded the result that there is negative relationship between them .

Kuan-Min Wang and Yuan-Ming Lee [10] in this paper they have collected the data from Japan stock excnahge.For this purpose they have utilize the unit root test. After checking the stationary of data they have concluded the result there is dynamic relationship between stock market of Japan and oil prices.

Grorge Handroyiannis and Evangelia Papapetrou [1] in this paper they have collected the data for checking the stationary of data from France stock exchange. For this purpose they have used the GARCH model and taken the results that there is long run relationship between oil prices and France stock exchange.

Teresiene, D. [9]In this paper they have influenced the impact of oil and gold prices on the stock market of LIthuaian.For this purpose they have utilized the VAR model and suggested they there is negative relationship between them.

\section{ECONOMETRIC MODEL AND METHODOLOGY}

In prime object of methodology to discuss about the different tools which has used for collection and interpretation of data.

\section{COLLECTION OF DATA}

In this study we have collected the data from secondary source. We have taken data from Karachi stock exchange for the period of 1996 to 2013 and monthly average of gold and oil prices have also taken.

\section{VARIABLES}

According to different researchers variable means such thing which could be change the result of investigation. In this research we have used four variables for example gold, oil prices and stock market returns. 


\section{OIL PRICES}

From last few years the oil prices have seen at high prices. Due to high price the economy are going to downward direction. From the last few decades the gold price is seen the decline the economy of any country.

\section{STOCK MARKET RETURNS}

Due to business activities the inventory of performance has impact on the financial markets.

Rt $=(\mathrm{Pn}-\mathrm{Po}) \times 100$

$\mathrm{P} 0$

\section{HYPOTHESIS}

Ho1: $\quad$ There is no relationship b/w Gold prices and Stock return

H1: $\quad$ There is relationship between gold prices and stock return

HO2: There is no s relationship between oil prices on stock return

$\mathrm{H} 2$ : $\quad$ There is significant relationship between oil prices and stock return

\section{EQUATIONS}

Gold $=\alpha \mathrm{O}+\beta 1 \mathrm{GDP}+\beta 2$ Market Index $+\varepsilon \mathrm{O}$

Oil $=\alpha \mathrm{O}+\beta 1 \mathrm{GDP}+\beta 2$ Market Index $+\varepsilon \mathrm{O}$

\section{THEROTICAL FRAME WORK}

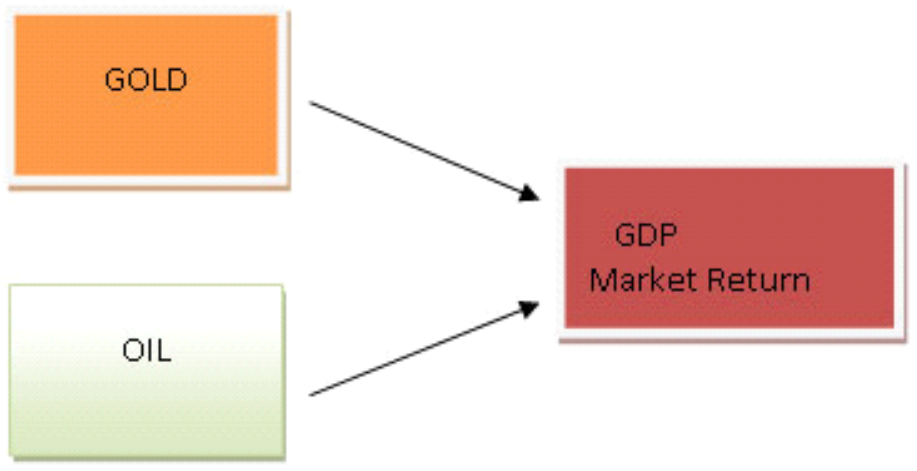

\section{DATA COLLECTION}

We have used that secondary data for this study. For this purpose we have taken data from Karachi stock exchange from the period of 1996 to 2013.

\section{DESCRIPTIVE STATISTICS}

\begin{tabular}{|l|l|l|l|l|}
\hline & GOLD & INDEX & OIL & GDP \\
\hline Mean & 0.012024 & 0.014503 & 0.009182 & 0.058793 \\
\hline Median & 0.008602 & 0.017724 & 0.0218 & 0.060258 \\
\hline Maximum & 0.102169 & 0.241105 & 0.256848 & 0.658961 \\
\hline Minimum & -0.124799 & -0.448795 & -0.403034 & -0.69236 \\
\hline Std. Dev. & 0.038716 & 0.089982 & 0.103375 & 0.071468 \\
\hline
\end{tabular}




\begin{tabular}{|l|l|l|l|l|}
\hline Skewness & -0.266157 & -1.114059 & -1.042828 & -1.12547 \\
\hline Kurtosis & 3.925806 & 7.719396 & 5.181338 & 8.821064 \\
\hline Jarque-Bera & 6.272588 & 149.8046 & 50.09498 & 152.1478 \\
\hline Probability & 0.043444 & 0 & 0 & 0 \\
\hline Sum & 1.587355 & 1.914198 & 1.211947 & 1.814564 \\
\hline Sum Sq. Dev & 0.196355 & 1.060649 & 1.399896 & 1.078236 \\
\hline
\end{tabular}

In this table we are trying to represent the mean, median, standard deviation and skewness.the result has shown that KSE 100 has return is 0.014503 and GDP 0.058793 ,gold 0.012026 and oil 0.00919.karachi stock exchange return has standard value is 0.089982, while gold standard deviation 0.038716 and oil standard deviation value is 0.103375 .

\section{CORRELATION MATRIX}

In simple words collelation means if two random variables represent the value of each other's. The degree of correlation can be measured .These are two ways of measurement $r$,R.bothranges from- 1 to $+1 .-1$ is used to show the perfect negative colleraltion and +1 is used to show the positive correlation. there are three types of correlation .1) perfect correlation means move in the perfect direction.2) partly correlated means there is not proper relationship 3)uncorrelated means there is no correlation between their movements.

\begin{tabular}{|l|l|l|l|l|}
\hline & GOLD & OIL & INDEX & GDP \\
\hline GOLD & 1 & & & \\
\hline OIL & 0.190823 & 1 & 1 & 1 \\
\hline INDEX & -0.038618 & & & 1 \\
\hline GDP & -0.029455 & & & \\
\hline
\end{tabular}

The correlation results have shown that there is not significant relationship with KSE stock exchange. It is also shown that there is weak positive correlation between KSE 100 and stock return. The purpose of correlation is just to show relationship between variables not just show co integration between them.

ANALYSIS GOLD AND OIL PRICES FROM 1996 TO 2013

\begin{tabular}{|l|l|l|l|l|}
\hline YEAR & GOLD & OIL & GDP & RETURN \\
\hline 1996 & $12,750.83$ & 27.18 & 62.44 & 0.00582 \\
\hline 1997 & $13,450.83$ & 17.11 & 62.18 & -0.9688738 \\
\hline 1998 & $14,658.97$ & 23.21 & 62.98 & -0.9684993 \\
\hline 1999 & $15,772.91$ & 37.18 & 73.58 & -0.963206 \\
\hline 2000 & $16,789.28$ & 30.41 & 72.32 & -0.9638632 \\
\hline 2001 & $19,428.57$ & 29.65 & 72.32 & -0.9638812 \\
\hline 2002 & $23,283.83$ & 35.23 & 83.25 & -0.9584424 \\
\hline 2003 & $26,305.78$ & 46.61 & 97.99 & -0.9511079 \\
\hline 2004 & $30,520.17$ & 59.89 & 109.6 & -0.9453866 \\
\hline 2005 & $38,348.78$ & 67.64 & 137.27 & -0.9315754 \\
\hline 2006 & $49,172.66$ & 72.31 & 152.38 & -0.9240709 \\
\hline 2007 & $64,542.47$ & 99.07 & 170.09 & -0.9152989 \\
\hline 2008 & $95,464.81$ & 58.21 & 167.88 & -0.916442 \\
\hline
\end{tabular}




\begin{tabular}{|l|l|l|l|l|}
\hline 2009 & $119,277.51$ & 76.39 & 177.18 & -0.9118558 \\
\hline 2010 & $146,798.91$ & 90.53 & 213.68 & -0.8937395 \\
\hline 2011 & $150,723.81$ & 88.12 & 224.89 & -0.8882307 \\
\hline 2012 & $155,785.81$ & 91.55 & 236.63 & -0.882455 \\
\hline 2013 & $165,801.88$ & 99.89 & 245.12 & -0.8782968 \\
\hline
\end{tabular}

The correlations have shown that in these markets there is not positive relationship.karachi stock exchange and GDP have inverse relationship with gold market.these results have also shown thatoil growth has a significant relationship with KSE100 and GDP.for the prediaction correlation is not consider an authentic measure.

\begin{tabular}{|l|l|l|l|l|}
\hline Model & R & R Square & Adjusted R Square & $\begin{array}{l}\text { Std. Error of the } \\
\text { Estimate }\end{array}$ \\
\hline 1 & $.995 \mathrm{a}$ & .989 & .987 & 7.80894 \\
\hline
\end{tabular}

a. Predictors: (Constant), Oil, Gold

This table is helpful for intreprationof $r, r 2$ and adjusted $r 2$.with the help of these we can measure the strength of two variables.+1 values has shown that there is strong correlation between variables and -1 value has represented that there is negative correlation between these variables. Where $\mathrm{r}$ is .955 which is showing there is strong correlation and $\mathrm{r}$ square is .989 which show that large value and adjusted $r$ square is .986.

Table 6: Co efficient

\begin{tabular}{|c|c|c|c|c|c|c|}
\hline \multirow{2}{*}{\multicolumn{2}{|c|}{$\begin{array}{l}\text { Model } \\
\text { B }\end{array}$}} & \multirow{2}{*}{\multicolumn{2}{|c|}{$\begin{array}{l}\text { Unstandardized Coefficients } \\
\text { Std. Error }\end{array}$}} & $\begin{array}{l}\text { Standardized } \\
\text { Coefficients }\end{array}$ & $\mathrm{t}$ & Sig. \\
\hline & & & & \multicolumn{3}{|l|}{ Beta } \\
\hline 1 & (Constant) & 30.694 & 4.845 & & 6.337 & .000 \\
\hline \multicolumn{2}{|c|}{ Gold } & .002 & .000 & .570 & 10.744 & .000 \\
\hline \multicolumn{2}{|c|}{ Oil } & 1.054 & .127 & .456 & 8.404 & .000 \\
\hline \multicolumn{4}{|c|}{ a. Dependent Variable: GDP } & & & \\
\hline
\end{tabular}

That table shows the GDP is constant because that is a dependent variable. The GDP is highly significant because the value is .000 if the value is less than .5 than the model is suitable. The impact of Gold and Oil have resulted with GDP is highly significant.

In this table we have taken GDP as dependent variable it is constant the value of GDP is showing highly significant because its value is less than .5 and model is suitable.

\begin{tabular}{|l|l|l|l|l|}
\hline Model & R & R Square & Adjusted R Square & $\begin{array}{l}\text { Std. Error of the } \\
\text { Estimate }\end{array}$ \\
\hline 1 & $.158 \mathrm{a}$ & .026 & -.106 & .23444 \\
\hline a. Predictors: (Constant), Oil, Gold & & \\
\hline
\end{tabular}

This table shows that $r, r$ square and adjusted $r$ square the large value of .158 indicates that there is positive relationship between these variables .r square value indicates that model is according to data and adjust $r$ square value -1.06 it is used to correct $r$ square. 


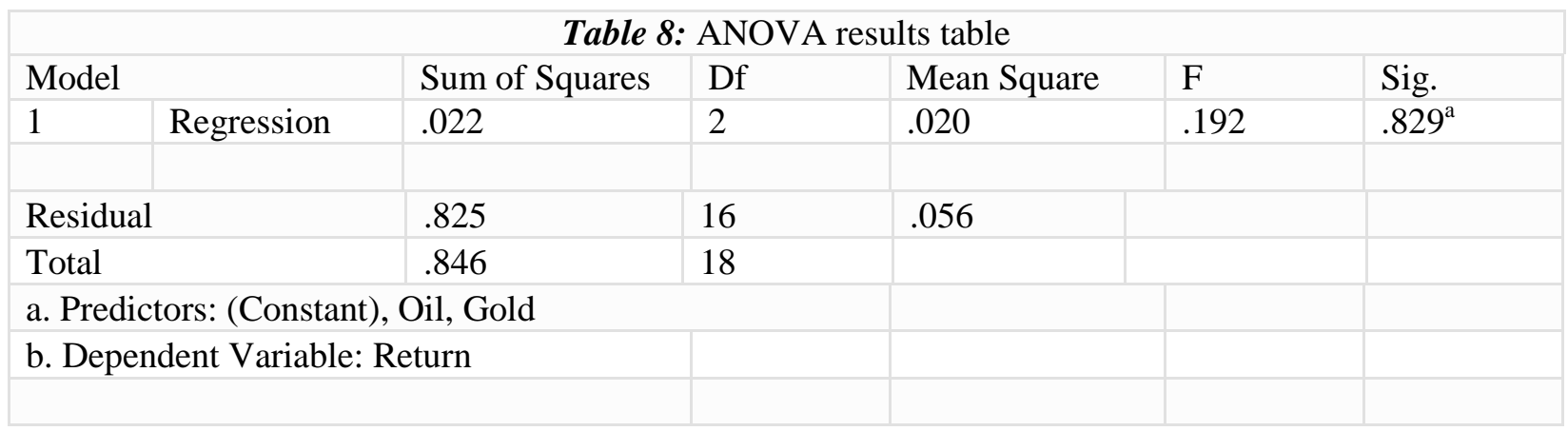

This table is trying to explain that there is large sum of square. The degree of freedom is the no of the years. The value of significant is .829.the mean is showing more close to the model. If value is less than .05 then model is not fit to the date.

\begin{tabular}{|c|c|c|c|c|c|c|}
\hline \multirow{2}{*}{\multicolumn{2}{|c|}{$\begin{array}{l}\text { Model } \\
\text { B }\end{array}$}} & \multirow{2}{*}{\multicolumn{2}{|c|}{$\begin{array}{l}\text { Unstandardized Coefficients } \\
\text { Std. Error }\end{array}$}} & $\begin{array}{l}\text { Standardized } \\
\text { Coefficients }\end{array}$ & $\mathrm{t}$ & Sig. \\
\hline & & & & \multicolumn{3}{|l|}{ Beta } \\
\hline 1 & (Constant) & -.797 & .146 & & -5.477 & .000 \\
\hline \multicolumn{2}{|c|}{ Gold } & $4.534 \mathrm{E}-7$ & .000 & .116 & .241 & .814 \\
\hline \multicolumn{2}{|c|}{ Oil } & -.003 & .003 & -.243 & -.508 & .621 \\
\hline
\end{tabular}

That table shows stock exchange return is constant because that is a dependent variable. The return is highly significant because the value is .000 if the value is less than .5 than the model is suitable. The impact of gold have a result with return is not significant. The impact of oil has resulted with return that is not significant. The gold and oil no significant result on stock returns. This means that there is no impact of Gold prices and Oil prices on Karachi Stock Exchange returns. So we can say that null hypothesis is verified

In this table stock exchange return is dependent variable. The return is seen as highly significant because value is less than .05.it means model is according to data. These results are showing that gold and oil has not significant impact on oil and gold.

\section{RECOMMENDATIONS}

1) In Pakistan, there is proper need of infrastructure of investment in obstacles of gold and oil.

2) Government should maintain political instability for the investment of the foreign investors.

3) For the development of the economy there is needed to invest in the oil and gold.

\section{CONCLUSION}

Different studies are showing that investors are not acting rationally and there are seen herding actions. The basic outcomes of this study are clearly exposing the poison of investment in gold and oil industry.oil and gold industry are the major area where investors like to invest. Oil and gold prices have impact on the economy of the country .Stock exchange is the backbone of any 
economy.oil and gold prices have impact on the stock market of all developing and under developing country. Foreign and local investors invest more in the gold investment it is long run investment.

\section{REFERENCE}

[1] Blose, L.E. and Shieh, J.C.P. (1995). "The Impact of Gold Price on the value of Gold Mining Stock”, Review of Financial Economics, Vol. 4, pp. 125-139

[2] Büyüksalvarcl, A. (2010). "The Effects of Macroeconomics Variables on Stock Returns: Evidence from Turkey” European Journal of Social Sciences, Vol. 14 No. 3, pp.404-416

[3] Capie, F., Mills, T., and Wood, G., (2005). "Gold as a hedge against the dollar”, Journal of International Financial Markets, Institutions, and Money, 15, 343-352

[4] Dickey, D., W.A. Fuller, (1979)."Distribution of the Estimates for Autoregressive Time Series with a Unit Root", Journal of the American Statistical Association, 74, 427-0431.

[5] Husing, Yu (2007), Impact of Higher Crude Oil Prices and Challenges Macroeconomic Conditions on Output Growth in Germany" International Research Journal of Finance and Economics, 2007.

[6] Ahmet, The Effect of Macroeconomics Variables on Stock Return: Evidence from Turkey, European Journal of Social Science - Volume 14, Number 3 (2010).

[7] Basher and Sadorsky, Oil price risk and emerging stock markets, Global Finance Journal 17 (2006) 224-251

[8] Claire, Ginette, Rajneesh and Ahmet, The Dynamics of Gold Prices, Gold Mining Stock prices and Stock Market Prices Co movements, Research in Applied Economics ,Issue 2009, Vol. 1, No. 1: E12

[9] Hamed Sadri and Elson TayebiSani (2012), the Impact of Crude Oil, Gold Price \& Their Volatilities on Stock Markets: Evidence from Selected Member of OPEC, Journal of Basic and Applied Scientific Research, 2(10)10472-10479, 2012.

[10] Basher and Sadorsky, Oil price risk and emerging stock markets, Globel Finance Journal 17 (2006) 224-251

[11] Subarna K. Samanta and Ali H. M. Zadeh (2011), Co-Movement of Oil, Gold, the US Dollar, and Stocks, Modern Economy, 2012,3, 111-117

[12] Mahmood Yahyazadehfar and Ahmad Babaie, Macroeconomic Variables and Stock Price, Middle-East Journal of Scientific Research 11 (4): 408-415, 2012

[13] Kuan-Min Wang and Yuan-Ming Lee, Could Gold Serve as Exchange Rate Hedge in Japan, Inzinerine Ekonomika-Engineerig Economics, 2010, 21(2), 160-170.

[14] Grorge Handroyiannis and Evangelia Papapetrou (2001), Macroeconomic Influences on the Stock Market, Journal of Economics and Finance, 25(1), 33-49.

[15] Teresiene, D. (2009). Lithuanian Stock Market Analysis Using a Set of GARCH Models. Journal of Business Economicsand Management, 10(4), 349-360. 